\title{
Interactive Effects between Corporate Governance, Executive Compensation, and Firm Performance of the Manufacturing Industry in Indonesia
}

\author{
Lini Ingriyani ${ }^{1}$, Dony Abdul Chalid ${ }^{2}$ \\ \{ingriyanilini@gmail.com ${ }^{1}$ \} \\ Universitas Indonesia, Indonesia ${ }^{1,2}$
}

\begin{abstract}
This study empirically investigates the interactive effect of executive compensation, firm performance, and corporate governance by adding aspects of monitoring and aligning incentives as suggested in agency theory. This study uses data of 51 manufacturing companies listed in the Indonesia Stock Exchange between 2014 and 2018. The data model used is dynamic panel data analyzed with System Generalized Method of Moments. The dynamic panel data model is used to describe relationships between dynamic variables, which can be seen from the existence of lag dependent variables between regressor variables. The study uses GMM approach to account for the problem of potential endogeneity and unobserved heterogeneity that arises due to the potential reverse causality. We found evidence of a significant positive reciprocal relationship between executive compensation and corporate governance. From the results of this study found that the reciprocal relationship lies in corporate governance, executive compensation, and company performance. This research is expected to have profound implications for corporate governance strategies and executive compensation to improve future firm performance. Our findings thus add several knowledges about executive compensation on an emerging market that uses the two-tier system, especially for policymakers and other stakeholders to make optimal governance systems.
\end{abstract}

Keywords: Executive Compensation, Firm Performance, Corporate Governance, Manufacture, Indonesia

\section{Introduction}

The ownership structure of companies in Indonesia is mostly family as the main owner and controlled by the family. More than $90 \%$ of the company's population in Indonesia is a family business and is controlled by the family. Susanto states that research in more developed countries shows that most of the founders of family companies do not want their offspring to work in these companies. Whereas in Indonesia, the results of research conducted by The Jakarta Consulting Group published in 2006 of 87 middle to upper-scale family companies spread across several cities in Indonesia showed that the majority of family company founders wanted their children to enter the company, and the responses from family members also show they really want to work in the family business [1].

Family involvement in business has the potential to increase or decrease financial performance caused by agency cost. This agency cost can arise when a family company employs 
outsiders as an agent in the company. Companies managed by families will have an agency cost level of zero [2] [3] [4].

According to the theory of Fama and Jensen [3], agency problems that occur between owners and company management can be reduced or minimized by having a family who occupies one of the positions in management because decision making and control are carried out by the same agent namely family members so as to minimize agency costs which appears to monitor the decisions made. From the theory presented above, it is suspected that a company with a concentration of family ownership and family involvement in the company can reduce conflicts that may occur and minimize costs arising from the conflict. In fact, family businesses are prone to conflict [1]. Conflicts that may occur in family businesses are conflicts between business and family interests, conflicts between family members, and conflicts between family and employees. Therefore, controlling agency problems and agency costs is needed, one of them is by implementing good corporate governance. Essentially, company that pays attention to the structure, systems and processes of corporate governance is company that implement corporate governance, which can be analyzed from corporate governance, firm performance, and executive compensation.

The author will provide a view of a broader (tri-directional) interactive relationship between corporate governance, firm performance, and executive compensation. In compiling this study, the author was inspired by several studies including those conducted by Omar $\mathrm{Al}$ Farooque and colleagues on "Interactive effects of executive compensation, firm performance and corporate governance: Evidence from an Asian market". They suggest that in publicly listed companies in Thailand, a significant reciprocal relationship exists between performance and compensation, and between performance and corporate governance. However, no the reciprocal relationship was found in compensation and corporate governance, what is found is the amonodirectional relationship of corporate governance to compensation not on the contrary. Different results obtained by research conducted by Martin J. Conyon, entitled "Executive Compensation and Board of Governance in Us Firms" which states that there is executive compensation with firm performance and company size. These different results encourage the author to try to retest the three variables. In addition, what distinguishes this research from the research conducted by Omar Al Farooque and Martin J. Conyon is the corporate governance system used. Their research analyzes companies with a one-tier corporate governance system. Whereas this research will analyze companies in Indonesia where the corporate governance system in Indonesia is two-tier.

\section{Hypothesis Development}

\subsection{Relationship of Firm Performance and Corporate Governance to Executive Compensation}

Many studies were examining the relationship between firm performance and executive compensation have shown a positive relationship. Core et al. [19] and Swatdikun [20] prove that market-based performance has a positive relationship with executive compensation. In addition, Conyon [18], Raithatha and Komera [21] in their research prove that there is a relationship between accounting based and market-based performance with executive compensation. Ntim [14] also states that company performance (total shareholder profits) has a significant effect on executive compensation. In addition, based on the theory underlying agency 
relationship expressed by Jensen and Murphy [2], it is stated that executives are compensated based on company performance. Good corporate performance forms the basis for an executive incentive system and better performers pay a larger nominal number of owned executives. Therefore, the authors hypothesize that company performance has an impact on Executive compensation.

$\mathrm{H} 1 \mathrm{a}=\mathrm{It}$ is suspected that the company's performance has a significant positive effect on executive compensation.

Several studies have also found that executive compensation is not only influenced by company performance, but is also influenced by corporate governance, either directly or indirectly. Cyert et al. [22] identified that executive compensation in cash is greater when executives have a greater proportion of independent executives. Research by Conyon and $\mathrm{He}$ [23] also supports the opinion, companies that have a proportion of independent boards are more likely to replace boards with poor performance and offer greater compensation for boards with good performance. As for the sub-committee of the board, the nomination committee and the remuneration committee have an important role in finding the board that meets the qualifications and arranging the board incentive agreement. Conyon and Peck [24] found a relationship between executive compensation and the remuneration committee, but did not find a relationship between executive compensation and the nomination committee. In addition, Conyon and $\mathrm{He}$ [23], Luo and Jackson [24] state that there is a significant negative relationship between family firms and executive compensation. Swatdikun [20] also adds that concentrated companies put more pressure on providing compensation to executives. Therefore, based on previous studies which suggest a link between corporate governance and executive compensation, the authors suspect that there is a link.

$\mathrm{H} 1 \mathrm{~b}=$ The corporate governance mechanism has a significant positive effect on executive compensation.

\subsection{Relationship of Corporate Governance and Executive Compensation to Future Firm Performance}

Future firm performance can also be influenced by executive compensation. From the perspective of agency theory, compensation or incentives are predicted to be useful to ensure that managers act in the interests of the company in line with the interests of shareholders. Compensation contracts can influence executive behavior so that executive interests are aligned with the interests of shareholders by rewarding executives for maximizing shareholder wealth [5] [6] [7].

High compensation motivates executives to create a better overall quality of the company's financial performance. This is because a company's financial performance reflects the ability of executives to achieve and manage the company's goals in maximizing shareholder wealth [8].

Therefore, to maximize the value of the company for the mutual benefit of owners and executives is needed a well-designed compensation system.

$\mathrm{H} 2 \mathrm{a}=$ Executive compensation has a significant positive effect on the company's future performance. 
The link between firm performance and corporate governance has often been investigated to confirm the interests of shareholders whether it has been effectively protected by corporate governance, it is recognized that better corporate performance results from the quality of corporate governance [9] [10].

In the context of emerging markets, different governance structures, such as concentrated ownership (majority shares owned by managerial) help reduce agency problems and control self-serving managerial behavior [11].

Companies with concentrated ownership have also been assessed as trying to protect their investments and at the same time attract foreign investors that are not diversified in the company from the threat of potential competitors and ensure the survival of the company in the market. That's because implementing a recommended corporate governance system mechanism (such as more members with financial expertise, independent directors, Big-4 auditors, etc.) is considered important to reduce Type II agency conflicts that harm the interests of minority shareholders and to improve firm performance in the future. Therefore, the authors suspect that the company's performance impacts executive compensation.

$\mathrm{H} 2 \mathrm{~b}=$ The corporate governance mechanism has a significant positive effect on the company's future performance.

\subsection{Relationship of Firm Performance and Executive Compensation to Future Corporate Governance}

Firm performance on corporate governance may have a different relationship with corporate governance on company performance. Firm performance tends to have a significant effect on several corporate governance mechanisms, such as board structure, ownership structure, etc. Existing studies confirm that firm performance can influence corporate governance practices, specifically ownership and board structure [12].

In managerial companies or family companies, internal parties have a lot of wealth invested in their company, so they have more desire to manage the company better. Therefore, the company implements appropriate governance measures in accordance with the recommendations, as a pre-commitment to minority shareholder wealth is not expropriated. Such measures include reducing the level of control or ownership of managerial and/or family shares by increasing non-family managerial shareholdings, hiring quality audit firms, increasing the number of independent directors on the board, etc. In contrast, companies with concentrated owners that exercise control rights to take over wealth from minority shareholders usually face a decline in company value or even financial loss, reputational damage and threats from potential competitors. Resetting or even changing their future governance steps is something that can be done with poor financial performance [13].

Therefore, based on this literature, the authors argue that changes in several future governance mechanisms could be due to the firm performance.

$\mathrm{H} 3 \mathrm{a}=$ Firm performance has a significant positive effect on future corporate governance (such as changes in board structure, board size and proportion of independent boards).

From the perspective of agency theory, incentives and monitoring are alternative mechanisms of internal governance policies to measure whether managers act in harmony with shareholders' interests compared to maximizing personal interests, giving rise to type 2 agency 
conflicts. As explained earlier, managers who are also owners of companies manage compensation and work in the interests of the company to increase profits and dividends. When the compensation policy is carried out efficiently, it will be able to improve firm performance and prevent the occurrence of type 2 agency costs so that it will require less monitoring. In the end it can be concluded, the system's intensive can influence the monitoring mechanism as long as the system also represents the interests of other shareholders [14]. Therefore, based on the literature the authors argue that high-performance companies with optimal compensation for executives will require fewer monitoring mechanisms in the coming year.

$\mathrm{H} 3 \mathrm{~b}=$ Executive compensation has a significant negative effect on future corporate governance (such as changes in board structure, board size and the proportion of independent boards.

\section{Research Methods}

This study analyzed 51 selected companies using a purposive sampling method and then analyzed the possibility of an interactive (tri-directional) relationship between company performance, corporate governance, executive compensation, and using the research model in figure 1.

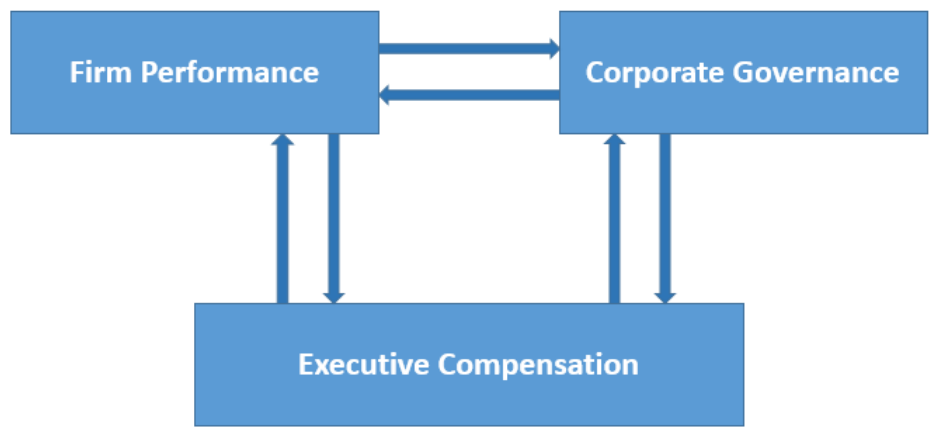

Fig. 1. Research Model

Table 1. Samples Taken

\begin{tabular}{lc}
\multicolumn{1}{c}{ Sample } & Amount \\
\hline Manufacturing companies listed on the IDX year 2014-2018 & 138 \\
Company Annual and Annual Reports Are Incomplete, Not Accessible & $(33)$ \\
Companies with Foreign Currency Financial Statements & $(21)$ \\
Companies with Incomplete Corporate Governance Data & $(30)$ \\
Companies with potential outlier data & $(3)$ \\
Total Company as Population & 51 \\
\hline
\end{tabular}

Source: Processed Data by Writer.

In this study, the independent and dependent variables will be divided into three categories, namely corporate governance, executive compensation, and firm performance. Moreover, 
control variables are needed so that external factors not examined do not affect the variables studied.

Table 2. Independent and Dependent Variable:

Executive Compensation, Performance and Corporate Governance

\begin{tabular}{|c|c|c|}
\hline Variable & Annotation & Measurement \\
\hline \multicolumn{3}{|c|}{ Executive compensation: } \\
\hline TECOMP & Total executive compensation & $\begin{array}{l}\text { Natural logarithm of total compensation } \\
\text { including fixed salary, benefits and bonuses } \\
\text { given to top executives in the fiscal year }\end{array}$ \\
\hline \multicolumn{3}{|c|}{ Firm performance: } \\
\hline $\mathrm{ROA}$ & Return on assets & Operational profit divided by total assets \\
\hline ROE & Return on equity & $\begin{array}{l}\text { Operational profit divided by shareholders' } \\
\text { equity }\end{array}$ \\
\hline RET & Return on stock & $\begin{array}{l}\text { Current stock price plus dividends paid, } \\
\text { divided by the initial stock price }\end{array}$ \\
\hline Q & Tobin’s Q & $\begin{array}{l}\text { The total market value of all outstanding } \\
\text { shares and corporate debt, divided by the } \\
\text { total book value of assets }\end{array}$ \\
\hline \multicolumn{3}{|c|}{ Corporate governance: } \\
\hline BCS & Board Commissioner Size & $\begin{array}{l}\text { Number of members on the board of } \\
\text { commissioners }\end{array}$ \\
\hline $\mathrm{IC}$ & Independence commissioner & $\begin{array}{l}\text { The proportion of independent } \\
\text { commissioners or outside members on the } \\
\text { board of commissioners }\end{array}$ \\
\hline BDS & Board Director size & $\begin{array}{l}\text { Number of members on the board of } \\
\text { directors }\end{array}$ \\
\hline ID & Independence Director & $\begin{array}{l}\text { The proportion of independent directors or } \\
\text { outside members on the board of } \\
\text { commissioners }\end{array}$ \\
\hline FO & Family Owner Ship & $\begin{array}{l}\text { Dummy Variable, value } 1 \text { if it is a family } \\
\text { company; } 0 \text { if it is not a family company }\end{array}$ \\
\hline ACS & Audit Committee Size & Number of members on the audit committee \\
\hline IAC & $\begin{array}{ll}\text { Audit } & \text { committee } \\
\text { independence } & \end{array}$ & $\begin{array}{l}\text { Proportion of independent directors on the } \\
\text { audit committee }\end{array}$ \\
\hline ENC & $\begin{array}{l}\text { Existence of a nomination } \\
\text { committee }\end{array}$ & $\begin{array}{l}\text { Value } 1 \text { when there is a nomination } \\
\text { committee }\end{array}$ \\
\hline ECC & $\begin{array}{l}\text { Existence of a compensation } \\
\text { committee }\end{array}$ & $\begin{array}{l}\text { Value } 1 \text { when there is a compensation } \\
\text { committee }\end{array}$ \\
\hline BCMF & $\begin{array}{l}\text { Board Commissioner Meeting } \\
\text { Frequency }\end{array}$ & $\begin{array}{l}\text { Number of Board of Commissioners } \\
\text { meetings in one fiscal year }\end{array}$ \\
\hline BDSF & \multirow{3}{*}{$\begin{array}{l}\text { Board Director } \\
\text { Frequency } \\
\text { Board Joint } \\
\text { frequency } \\
\text { Audit committee } \\
\text { frequency }\end{array}$} & $\begin{array}{l}\text { Number of meetings of the Board of } \\
\text { Directors in one fiscal year }\end{array}$ \\
\hline BMF & & $\begin{array}{l}\text { Number of joint board meetings in one } \\
\text { fiscal year }\end{array}$ \\
\hline $\mathrm{ACMF}$ & & Number of audit committee meetings \\
\hline
\end{tabular}


Table 3. Control Variable

\begin{tabular}{lll}
\hline Variable & \multicolumn{1}{c}{ Annotation } & \multicolumn{1}{c}{ Measurement } \\
\hline FS & Firm size & Natural logarithm of assets book value \\
\hline FAGE & Firm age & $\begin{array}{l}\text { The age of the company since the company was } \\
\text { founded as a public company }\end{array}$ \\
\hline GO & Growth opportunity & Market price per share divided by book value per share \\
\hline IR & Leverage & Proportion of debt to total assets \\
\hline BIG4 & Investment ratio & Capital expenditure divided by total assets \\
\hline
\end{tabular}

The data collected in this study is dynamic panel data. The dynamic panel data model is used to describe relationships between variables that in reality many are dynamic. The relationship between variables is basically a dynamic is the variable is not only influenced by the variable at the same time but is also influenced by the variable at the previous time. This dynamic panel model can be seen from the existence of lag dependent variables between regressor variables. The following models are used in this study:

Hypothesis 1: It is suspected that performance and governance positively influence compensation.

$$
\begin{aligned}
& \text { TECOMP }_{i t} \quad=\beta \mathrm{i}+\beta_{1} \text { TECOMP }_{\text {it }-1}+\beta_{2} \text { PERF }_{\text {it }}+\beta_{3} \text { BCS }_{\text {it }}+ \\
& \beta_{4} \mathrm{IC}_{\text {it }}+\beta_{5} \mathrm{BDS}_{\mathrm{it}}+\beta_{6} \mathrm{ID}_{\mathrm{it}}+\beta_{7} \mathrm{FO}_{\mathrm{it}}+\beta_{8} \mathrm{ACS}_{\mathrm{it}}+ \\
& \beta_{9} \mathrm{IAC}_{\text {it }}+\beta_{10} \mathrm{ENC}_{\mathrm{it}}+\beta_{11} \mathrm{ECC}_{\mathrm{it}}+\beta_{12} \mathrm{FS}_{\mathrm{it}}+ \\
& \beta_{13} \mathrm{FAGE}_{\text {it }}+\beta_{14} \mathrm{GO}_{\text {it }}+\beta_{15} \mathrm{PERF}_{\text {it- } 1}+\beta_{16} \mathrm{BCS} \\
& { }_{\mathrm{it}-1}+\beta_{17} \mathrm{IC}_{\mathrm{it}-1}+\beta_{18} \mathrm{BDS}_{\mathrm{it}-1}+\beta_{19} \mathrm{ID}_{\mathrm{it}-1}+\varepsilon_{\mathrm{it}}
\end{aligned}
$$

Hypothesis 2: It is suspected that governance and compensation positively affect future performance.

$$
\begin{aligned}
& \mathrm{PERF}_{i t+1}=\beta \mathrm{i}+\beta 1 \mathrm{PERF}_{i t}+\beta 2 \mathrm{TECOMP}_{i t}+\beta 3 \mathrm{BCS}_{\mathrm{it}}+\beta 4 \mathrm{IC}_{\mathrm{it}} \\
& +\beta 5 \mathrm{BDS}_{\mathrm{it}}+\beta 6 \mathrm{ID}_{\mathrm{it}}+\beta 7 \mathrm{FO}_{\mathrm{it}}+\beta 8 \mathrm{ACS}_{\mathrm{it}}+\beta 9 \mathrm{IAC}_{\mathrm{it}} \\
& +\beta 10 \mathrm{ENC}_{\mathrm{it}}+\beta 11 \mathrm{ECC}_{\mathrm{it}}+\beta 12 \mathrm{BCMF}_{\mathrm{it}}+ \\
& \beta 13 \mathrm{BDSF}_{\text {it }}+\beta 14 \mathrm{BMF}_{\text {it }}+\beta 15 \mathrm{ACMF}_{\text {it }}+\beta 16 \mathrm{FS}_{\text {it }} \\
& +\beta 17 \mathrm{FAGE}_{\mathrm{it}}+\beta 18 \mathrm{GO}_{\mathrm{it}}+\beta 19 \mathrm{LEV}_{\mathrm{it}}+\beta 20 \mathrm{IR}_{\mathrm{it}}+ \\
& \beta 21 \text { BIG }_{\text {it }}+\beta_{22} \text { TECOMP }_{\text {it }-1}+\beta_{23} \text { BCS }_{\text {it }-1}+\beta_{24} \text { IC } \\
& \text { it-1 }+\beta_{25} \mathrm{BDS}_{\mathrm{it}-1}+\beta_{26} \mathrm{ID}_{\mathrm{it}-1}+\varepsilon_{\text {it }}
\end{aligned}
$$

Hypothesis 3: It is suspected that performance and compensation affect future corporate governance (positive on-board composition and negative on ownership).

$$
\begin{aligned}
& \mathrm{BCS}_{\mathrm{it}+1}=\beta \mathrm{i}+\beta_{1} \mathrm{BCS}_{\mathrm{it}}+\beta_{2} \mathrm{PERF}_{\mathrm{it}}+\beta_{3} \mathrm{TECOMP}_{\mathrm{it}}+\beta_{4} \mathrm{IC}_{\mathrm{it}}+ \\
& \beta_{5} \mathrm{BDS}_{\text {it }}+\beta_{6} \mathrm{ID}_{\mathrm{it}}+\beta_{7} \mathrm{FO}_{\text {it }}+\beta_{8} \mathrm{ACS}_{\text {it }}+\beta_{9} \mathrm{IAC}_{\mathrm{it}}+ \\
& \beta_{10} \mathrm{ENC}_{\mathrm{it}}+\beta_{11} \mathrm{ECC}_{\mathrm{it}}+\beta_{12} \mathrm{FS}_{\mathrm{it}}+\beta_{13} \mathrm{FAGE}_{\mathrm{it}}+ \\
& \beta_{14} \mathrm{GO}_{\text {it }}+\beta_{15} \mathrm{LEV}_{\text {it }}+\beta_{16} \mathrm{IR}_{\text {it }}+\beta_{17} \mathrm{TECOMP}_{\text {it- } 1}+ \\
& \beta_{18} \mathrm{PERF}_{\text {it- } 1}+\varepsilon_{\text {it }} \\
& \mathrm{IC}_{\mathrm{it}+1}=\beta \mathrm{i}+\beta_{1} \mathrm{IC}_{\mathrm{it}}+\beta_{2} \mathrm{PERF}_{\mathrm{it}}+\beta_{3} \mathrm{TECOMP}_{\mathrm{it}}+\beta_{4} \mathrm{BCS}_{\mathrm{it}}+ \\
& \beta_{5} \mathrm{BDS}_{\mathrm{it}}+\beta_{6} \mathrm{ID}_{\mathrm{it}}+\beta_{7} \mathrm{FO}_{\mathrm{it}}+\beta_{8} \mathrm{ACS}_{\mathrm{it}}+\beta_{9} \mathrm{IAC}_{\mathrm{it}}+ \\
& \beta_{10} \mathrm{ENC}_{\mathrm{it}}+\beta_{11} \mathrm{ECC}_{\mathrm{it}}+\beta_{12} \mathrm{FS}_{\mathrm{it}}+\beta_{13} \mathrm{FAGE}_{\mathrm{it}}+
\end{aligned}
$$




$$
\begin{aligned}
& \beta_{14} \mathrm{GO}_{\text {it }}+\beta_{15} \mathrm{LEV}_{\text {it }}+\beta_{16} \mathrm{IR}_{\text {it }}+\beta_{17} \mathrm{TECOMP}_{\text {it }-1}+ \\
& \beta_{18} \text { PERF }_{\text {it }-1}+\varepsilon \text { it } \\
& \mathrm{BDS}_{\mathrm{it}+1}=\beta \mathrm{i}+\beta_{1} \mathrm{BDS}_{\mathrm{it}}+\beta_{2} \mathrm{PERF}_{\mathrm{it}}+\beta_{3} \mathrm{TECOMP}_{\mathrm{it}}+\beta_{4} \mathrm{BCS}_{\mathrm{it}} \\
& +\beta_{5} \mathrm{IC}_{\mathrm{it}}+\beta_{6} \mathrm{ID}_{\mathrm{it}}+\beta_{7} \mathrm{FO}_{\mathrm{it}}+\beta_{8} \mathrm{ACS}_{\mathrm{it}}+\beta_{9} \mathrm{IAC}_{\mathrm{it}}+ \\
& \beta_{10} \mathrm{ENC}_{\mathrm{it}}+\beta_{11} \mathrm{ECC}_{\mathrm{it}}+\beta_{12} \mathrm{FS}_{\mathrm{it}}+\beta_{13} \mathrm{FAGE}_{\mathrm{it}}+ \\
& \beta_{14} \mathrm{GO}_{\text {it }}+\beta_{15} \mathrm{LEV}_{\text {it }}+\beta_{16} \mathrm{IR}_{\text {it }}+\beta_{17} \mathrm{TECOMP}_{\text {it- } 1}+ \\
& \beta_{18} P_{\text {PERF }} \text { it- } 1+\varepsilon_{\text {it }} \\
& \mathrm{ID}_{\mathrm{it}+1}=\beta \mathrm{i}+\beta_{1} \mathrm{ID}_{\mathrm{it}}+\beta_{2} \mathrm{PERF}_{\mathrm{it}}+\beta_{3} \mathrm{TECOMP}_{\mathrm{it}}+\beta_{4 \mathrm{BCS}_{\mathrm{it}}+}+ \\
& \beta_{5} \mathrm{IC}_{\text {it }}+\beta_{6} \mathrm{BDS}_{\text {it }}+\beta_{7} \mathrm{FO}_{\text {it }}+\beta_{8} \mathrm{ACS}_{\text {it }}+\beta_{9} \mathrm{IAC}_{\text {it }}+ \\
& \beta_{10} \mathrm{ENC}_{\mathrm{it}}+\beta_{11} \mathrm{ECC}_{\mathrm{it}}+\beta_{12} \mathrm{FS}_{\mathrm{it}}+\beta_{13} \mathrm{FAGE}_{\mathrm{it}}+ \\
& \beta_{14} \mathrm{GO}_{\text {it }}+\beta_{15} \mathrm{LEV}_{\text {it }}+\beta_{16} \mathrm{IR}_{\text {it }}+\beta_{17} \mathrm{TECOMP}_{\text {it- } 1}+
\end{aligned}
$$

From the model above, when an equation contains lag of the dependent variable, then there will be a problem in the form of a correlation between the variables yi, $t-1$ with uit. That is because yi,t-1 is a function of $\mu \mathrm{i}$. The use of estimations with static panels such as OLS, fixed effects and random effects on dynamic panel equations is biased and inconsistent even though vit does not correlate serially [15]. This research uses SYS-GMM. Blundell and Blond [26] state that in small samples, the FD-GMM estimator can contain bias and inaccuracy. In addition, the instrument in the form of lagged level in the first-difference equation is a weak instrument in FD-GMM. Therefore, the importance of utilizing initial conditions in producing an efficient estimator of the dynamic panel data model when having a short time series. Blundel and Bond

\begin{tabular}{|c|c|c|c|c|c|}
\hline \multirow{2}{*}{ Independent Variable } & \multirow{2}{*}{ Expected Sign } & \multicolumn{4}{|c|}{ Dependent Variable: TECOMP } \\
\hline & & (1) & $(2)$ & (3) & (4) \\
\hline $\mathrm{ROA}$ & + & $\begin{array}{l}0.9362 \\
0.0000\end{array}$ & & & \\
\hline ROE & + & & $\begin{array}{l}0.3674 \\
0.0000\end{array}$ & & \\
\hline RET & + & & & $\begin{array}{l}0.0439 \\
0.0000\end{array}$ & \\
\hline $\mathrm{Q}$ & + & & & & $\begin{array}{l}0.0530 \\
0.0000\end{array}$ \\
\hline BDS & + & 0.1152 & 0.1144 & 0.1026 & 0.0862 \\
\hline
\end{tabular}
[26] suggest using the Generalized Method of Moments System (Blundell and Bond GMMSystem Estimator) which is claimed to be more efficient than the previous estimator. That is because the use of additional level information that is the moment condition and level instrument variable matrix besides the first difference by combining the condition moment and the instrument variable matrix (first difference and level).

\section{Result and Discussion}

\subsection{Relationship of Firm performance and Corporate Governance to Executive Compensation (Eq. 1)}

Table 4. Regression Results of Eq. 1 regarding Relationship of Firm performance and Corporate Governance to Executive Compensation using SYS-GMM 


\begin{tabular}{|c|c|c|c|c|c|}
\hline & & 0.0000 & 0.0000 & 0.0000 & 0.0000 \\
\hline \multirow{2}{*}{ ID } & \multirow{2}{*}{+} & 2.0479 & 1.7490 & 1.4289 & 1.0225 \\
\hline & & 0.0000 & 0.0000 & 0.0000 & 0.0000 \\
\hline \multirow{2}{*}{$\mathrm{BCS}$} & \multirow{2}{*}{+} & 0.0185 & 0.0432 & 0.0406 & 0.0299 \\
\hline & & 0.4300 & 0.0410 & 0.0270 & 0.2600 \\
\hline \multirow{2}{*}{ IC } & \multirow{2}{*}{+} & 0.2281 & 0.0339 & -0.1999 & -0.0583 \\
\hline & & 0.1820 & 0.9060 & 0.4760 & 0.8340 \\
\hline \multirow{2}{*}{ FO } & \multirow[b]{2}{*}{ - } & -0.2349 & -0.1454 & -0.1118 & -0.2117 \\
\hline & & 0.0610 & 0.1640 & 0.2340 & 0.1250 \\
\hline \multirow{2}{*}{ ACS } & \multirow{2}{*}{ - } & -0.0867 & -0.0828 & -0.0631 & -0.0401 \\
\hline & & 0.0960 & 0.0420 & 0.2360 & 0.6310 \\
\hline \multirow{2}{*}{ IAC } & \multirow{2}{*}{+} & 0.1388 & 0.6002 & 0.0638 & 0.2095 \\
\hline & & 0.7540 & 0.1420 & 0.8670 & 0.4570 \\
\hline \multirow{2}{*}{$\mathrm{ENC}$} & \multirow{2}{*}{+} & 0.4699 & 0.7590 & 0.6776 & 0.9872 \\
\hline & & 0.3930 & 0.1080 & 0.0340 & 0.0800 \\
\hline \multirow{2}{*}{ ECC } & \multirow{2}{*}{ - } & -0.7094 & -1.0230 & -0.8374 & -1.2079 \\
\hline & & 0.1810 & 0.0280 & 0.0130 & 0.0280 \\
\hline \multirow{2}{*}{$\operatorname{lnFS}$} & \multirow{2}{*}{+} & 0.3094 & 0.3532 & 0.2569 & 0.2502 \\
\hline & & 0.0000 & 0.0000 & 0.0000 & 0.0000 \\
\hline \multirow{2}{*}{ FAGE } & \multirow{2}{*}{+} & 0.0056 & 0.0081 & 0.0054 & 0.0061 \\
\hline & & 0.1960 & 0.0350 & 0.2140 & 0.1610 \\
\hline \multirow{2}{*}{ GO } & \multirow{2}{*}{-} & -0.0205 & -0.0183 & -0.0141 & -0.0171 \\
\hline & & 0.0000 & 0.0000 & 0.0000 & 0.0000 \\
\hline \multirow{2}{*}{ lnTECOMPt-1 } & \multirow[b]{2}{*}{+} & 0.6625 & 0.6225 & 0.7028 & 0.7180 \\
\hline & & 0.0000 & 0.0000 & 0.0000 & 0.0000 \\
\hline ROAt-1 & + & $\begin{array}{l}0.3221 \\
0.2990\end{array}$ & & & \\
\hline & + & & 0.0179 & & \\
\hline KUEL-1 & + & & 0.8420 & & \\
\hline RETt-1 & - & & & -0.0606 & \\
\hline & & & & & -0.0217 \\
\hline$Q-1$ & - & & & & 0.0900 \\
\hline BDSt-1 & - & -0.0596 & -0.0394 & -0.0520 & -0.0423 \\
\hline DDSI-1 & 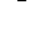 & 0.0110 & 0.1460 & 0.0000 & 0.0020 \\
\hline IDt-1 & - & -0.7338 & -0.8573 & -0.4021 & -0.2610 \\
\hline $1 D t-1$ & - & 0.0110 & 0.0070 & 0.1650 & 0.2830 \\
\hline BCSt-1 & - & -0.0438 & -0.0699 & -0.0814 & -0.0926 \\
\hline Dest-1 & - & 0.0950 & 0.0190 & 0.0060 & 0.0000 \\
\hline ICt_1 & + & 1.2693 & 1.5373 & 1.1965 & 0.9681 \\
\hline $1 C l-1$ & ${ }^{+}$ & 0.0000 & 0.0000 & 0.0000 & 0.0000 \\
\hline Arellano-Bond m1 & & -2.9074 & -2.7903 & -3.0354 & -3.1119 \\
\hline Arellano-Bond $\mathrm{m} 2$ & & 0.6795 & 0.5818 & 0.7709 & 0.9081 \\
\hline Sargan Test & & 37.3424 & 35.3508 & 33.8908 & 32.8849 \\
\hline Number of Samples & & 204 & 204 & 204 & 204 \\
\hline Number of Group & & 51 & 51 & 51 & 51 \\
\hline
\end{tabular}

Source: Processed Data by Writer. 
From the regression results of equation 1, it can be seen that corporate governance and company performance show a significant positive effect on executive compensation. This indicates that the increase in executive compensation is influenced by the larger board structure and also the better company performance in terms of accounting and market-based performance. In addition, by increasing the monitoring side of corporate governance, it will reduce over spending on executive compensation.

\subsection{Relationship of Corporate Governance and Executive Compensation to Future Firm performance (Eq. 2)}

Table 5. Regression Results of Eq.2 regarding Relationship of Corporate Governance and Executive Compensation to the Future Firm Performance using SYS-GMM

\begin{tabular}{|c|c|c|c|c|c|}
\hline \multirow{2}{*}{ Independent Variable } & \multirow{2}{*}{ Expected Sign } & \multicolumn{4}{|c|}{ Dependent Variable: F.PERF } \\
\hline & & (1) & (2) & (3) & (4) \\
\hline \multirow{2}{*}{ TECOMP } & \multirow{2}{*}{+} & 0.0126 & 0.0272 & 0.1749 & -0.3552 \\
\hline & & 0.3760 & 0.4710 & 0.4980 & 0.0740 \\
\hline \multirow{2}{*}{$\mathrm{BCS}$} & \multirow{2}{*}{ \pm} & 0.0016 & -0.0254 & -0.0629 & 0.0542 \\
\hline & & 0.7740 & 0.2710 & 0.4920 & 0.6250 \\
\hline \multirow{2}{*}{$\mathrm{IC}$} & \multirow[b]{2}{*}{+} & 0.0428 & -0.3303 & 1.5756 & 2.9096 \\
\hline & & 0.4960 & 0.0380 & 0.2140 & 0.0000 \\
\hline \multirow{2}{*}{ BDS } & \multirow{2}{*}{-} & 0.0028 & -0.0245 & 0.0580 & 0.1279 \\
\hline & & 0.6320 & 0.1660 & 0.5700 & 0.1940 \\
\hline \multirow{2}{*}{ ID } & \multirow{2}{*}{ \pm} & 0.0017 & -0.3059 & 1.7884 & 1.0378 \\
\hline & & 0.9910 & 0.2510 & 0.5220 & 0.5590 \\
\hline \multirow{2}{*}{ FO } & \multirow{2}{*}{ \pm} & 0.0145 & 0.0922 & -1.4300 & -0.0096 \\
\hline & & 0.7010 & 0.2330 & 0.1680 & 0.9860 \\
\hline \multirow{2}{*}{$\mathrm{ACS}$} & \multirow{2}{*}{ \pm} & -0.0053 & 0.0533 & -0.4699 & -0.7323 \\
\hline & & 0.6360 & 0.0900 & 0.1230 & 0.0110 \\
\hline \multirow{2}{*}{ IAC } & \multirow{2}{*}{ \pm} & 0.0813 & -0.3206 & -0.3482 & 0.7643 \\
\hline & & 0.1650 & 0.2090 & 0.8520 & 0.5990 \\
\hline \multirow{2}{*}{ ENC } & \multirow[b]{2}{*}{-} & 0.1919 & -0.6537 & 1.2549 & 3.8424 \\
\hline & & 0.1590 & 0.1950 & 0.6220 & 0.0120 \\
\hline \multirow{2}{*}{$\mathrm{ECC}$} & \multirow{2}{*}{-} & -0.1969 & 0.6475 & -1.5278 & -3.7270 \\
\hline & & 0.1210 & 0.2140 & 0.5710 & 0.0110 \\
\hline \multirow{2}{*}{ BDSF } & \multirow{2}{*}{ \pm} & -0.0003 & -0.0027 & 0.0202 & 0.0045 \\
\hline & & 0.6770 & 0.0340 & 0.0110 & 0.6340 \\
\hline \multirow{2}{*}{ BCMF } & \multirow[t]{2}{*}{+} & -0.0031 & -0.0038 & 0.0685 & -0.0171 \\
\hline & & 0.0760 & 0.3570 & 0.0000 & 0.4980 \\
\hline \multirow{2}{*}{ BMF } & & 0.0029 & -0.0010 & 0.0097 & 0.0522 \\
\hline & + & 0.1540 & 0.7320 & 0.7650 & 0.0650 \\
\hline MF & t & 0.0026 & 0.0064 & 0.0041 & -0.0357 \\
\hline ACIVI & $T$ & 0.0000 & 0.0000 & 0.6690 & 0.0540 \\
\hline $\ln F S$ & + & 0.0098 & 0.0462 & -0.0857 & 0.4176 \\
\hline IIITS & $T$ & 0.3370 & 0.1520 & 0.6240 & 0.0550 \\
\hline FAGE & & -0.0011 & 0.0074 & -0.0246 & -0.0256 \\
\hline FAUE & + & 0.3940 & 0.0020 & 0.2560 & 0.2660 \\
\hline GO & & -0.0008 & 0.0022 & 0.0290 & 0.1863 \\
\hline 0 & + & 0.3240 & 0.6140 & 0.3150 & 0.0000 \\
\hline
\end{tabular}




\begin{tabular}{|c|c|c|c|c|c|}
\hline \multirow{2}{*}{ LEV } & \multirow{2}{*}{ \pm} & -0.0045 & 0.0216 & -0.1618 & -0.2466 \\
\hline & & 0.2150 & 0.5120 & 0.3720 & 0.1780 \\
\hline \multirow{2}{*}{ IR } & \multirow[b]{2}{*}{+} & -0.0782 & 0.3701 & 2.0957 & 0.3818 \\
\hline & & 0.3210 & 0.0710 & 0.0200 & 0.6290 \\
\hline \multirow{2}{*}{ BIG4 } & \multirow{2}{*}{+} & 0.0345 & 0.0299 & 0.7183 & 1.3122 \\
\hline & & 0.1130 & 0.4030 & 0.0610 & 0.0210 \\
\hline ROA & + & $\begin{array}{l}0.5998 \\
0.0000\end{array}$ & & & \\
\hline ROE & + & & 0.6295 & & \\
\hline & & & \multirow{2}{*}{\multicolumn{2}{|c|}{$\begin{array}{l}0.5769 \\
0.0000\end{array}$}} & \\
\hline REI & + & & & & \\
\hline Q & + & & & & 0.1267 \\
\hline \multirow{2}{*}{ TECOMPt-1 } & \multirow{2}{*}{-} & -0.0165 & -0.0842 & -0.0577 & 0.0841 \\
\hline & & 0.3080 & 0.0360 & 0.8220 & 0.7580 \\
\hline \multirow{2}{*}{ BDSt-1 } & \multirow{2}{*}{+} & 0.0019 & 0.0433 & -0.1809 & -0.1791 \\
\hline & & 0.8500 & 0.0730 & 0.3180 & 0.2010 \\
\hline \multirow{2}{*}{ IDt-1 } & \multirow{2}{*}{ \pm} & 0.0238 & 0.1391 & -0.9813 & -2.1332 \\
\hline & & 0.8700 & 0.6200 & 0.5290 & 0.2080 \\
\hline \multirow{2}{*}{ BCSt-1 } & \multirow{2}{*}{ - } & -0.0130 & -0.0008 & -0.1129 & -0.1779 \\
\hline & & 0.0790 & 0.9720 & 0.3090 & 0.2530 \\
\hline \multirow{2}{*}{ ICt-1 } & \multirow{2}{*}{+} & 0.0881 & 0.1665 & 1.1601 & 1.1156 \\
\hline & & 0.2790 & 0.4080 & 0.4610 & 0.2700 \\
\hline Arellano-Bond m1 & & 0.0353 & 0.2410 & 0.8665 & 0.2143 \\
\hline Arellano-Bond m2 & & 0.3149 & 0.3176 & 0.5993 & 0.1963 \\
\hline Sargan Test & & 30.58 & 21.95 & 25.12 & 27.17 \\
\hline Number of Samples & & 204 & 204 & 204 & 204 \\
\hline Number of Group & & 51 & 51 & 51 & 51 \\
\hline
\end{tabular}

From the results of the regression model of hypothesis 2 above, it appears that good corporate governance will increase public confidence in company performance. The relationship between corporate governance and company performance, the greater the proportion of independent commissioners and the supervisory function in the company, the more public trust will be seen from the improvement in the company's march-based performance. While executive compensation has a significant negative effect on market-based performance, especially on Tobin's Q, this indicates that the greater the compensation provided, the company's market performance will decline. In addition, it can be concluded that the larger the executive compensation does not have a significant effect on executive motivation to improve company performance. 
4.3 Relationship of Firm performance and Executive Compensation to Future Corporate Governance (Eq. 3-6)

Table 6. Regression Results of Eq. 3 regarding Relationship of Firm performance and Executive Compensation to Board Commissioner Size using SYS-GMM

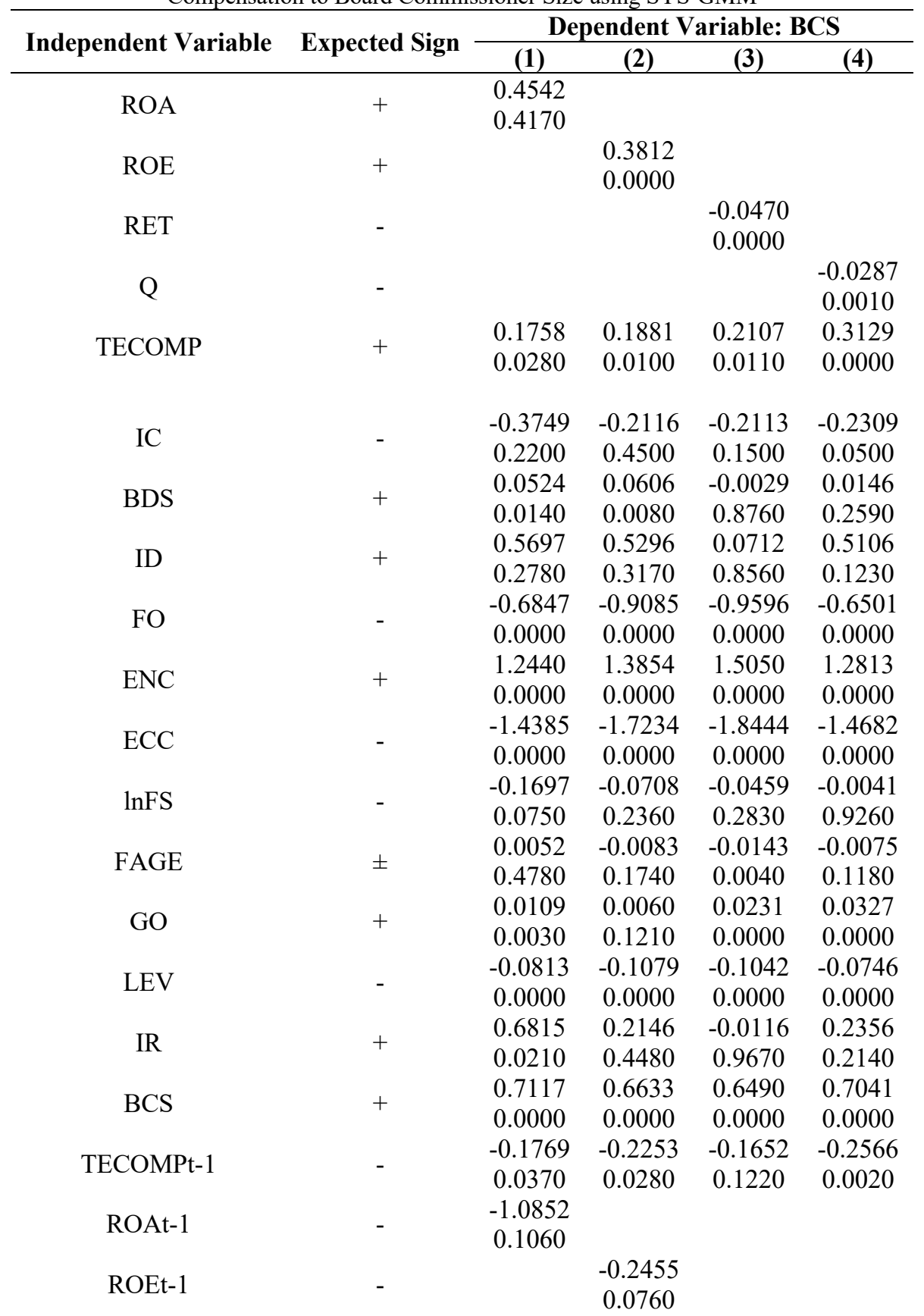


RETt-1

$-0.0414$

0.0000

Qt-1

$-0.0433$

Arellano-Bond $\mathrm{m} 1$

Arellano-Bond $\mathrm{m} 2$

Sargan Test

Number of Samples

Number of Group

Source: Processed Data by Writer.

$\begin{array}{cccc}0.0253 & 0.0227 & 0.0276 & 0.0248 \\ 1.0761 & 0.8695 & 0.7233 & 1.0761 \\ 31.73 & 36.10 & 36.96 & 36.44 \\ 204 & 204 & 204 & 204 \\ 51 & 51 & 51 & 51\end{array}$

Table 7. Regression Results of Eq. 4 regarding Relationship of Firm performance and Executive Compensation to the Independent Commissioner's Proposition using SYS-GMM

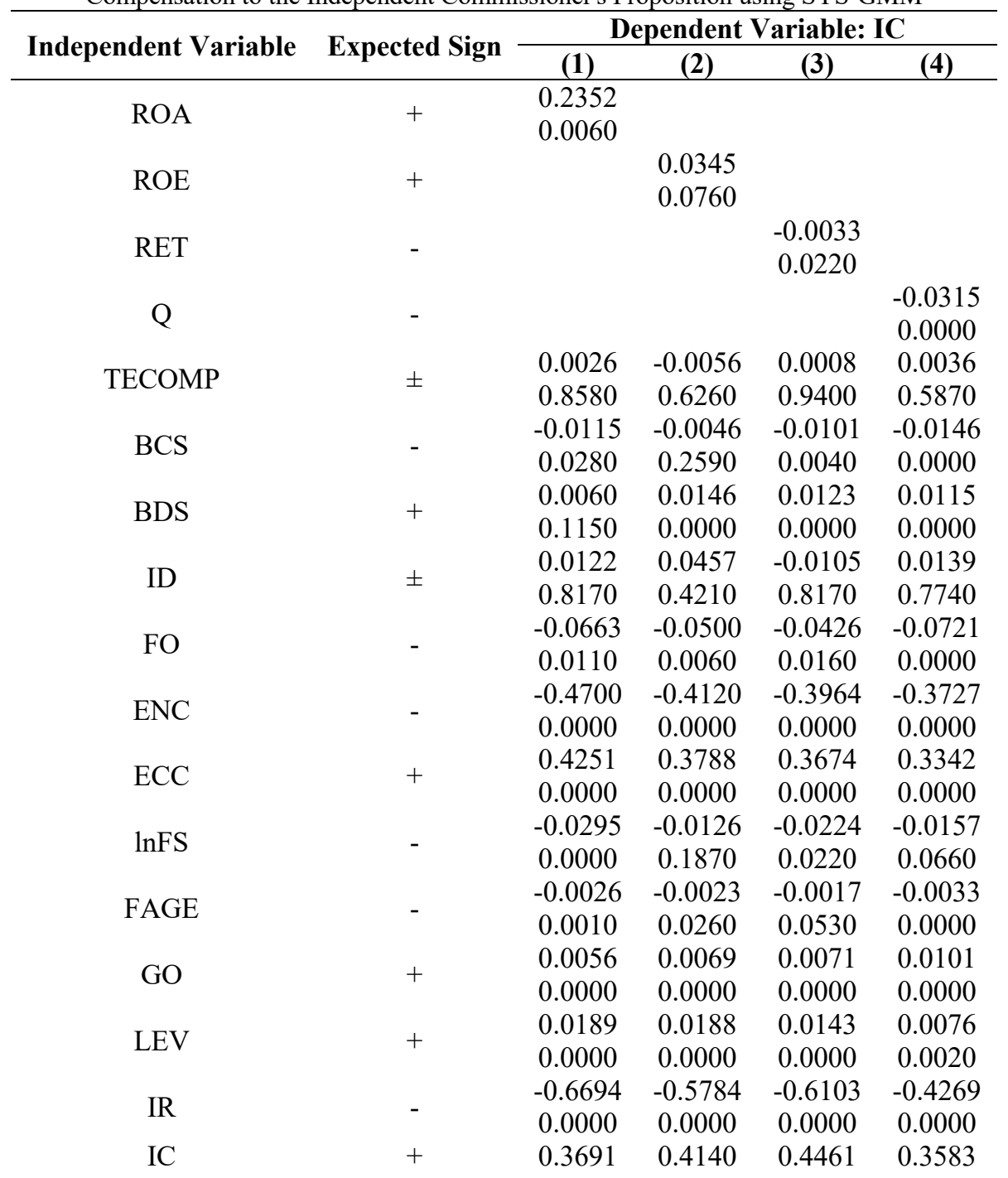




\begin{tabular}{|c|c|c|c|c|c|}
\hline \multirow{3}{*}{ TECOMPt-1 } & \multirow{3}{*}{+} & 0.0000 & 0.0000 & 0.0000 & 0.0000 \\
\hline & & 0.0343 & 0.0305 & 0.0283 & 0.0287 \\
\hline & & 0.0100 & 0.0030 & 0.0110 & 0.0010 \\
\hline ROAt-1 & - & $\begin{array}{l}0.0346 \\
0.6230\end{array}$ & & & \\
\hline ROEt-1 & - & & $\begin{array}{c}-0.0298 \\
0.2240\end{array}$ & & \\
\hline RETt-1 & + & & & $\begin{array}{l}0.0003 \\
0.8550\end{array}$ & \\
\hline Qt-1 & + & & & & $\begin{array}{l}0.0208 \\
0.0000\end{array}$ \\
\hline Arellano-Bond m1 & & 0.0134 & 0.0294 & 0.0126 & 0.0122 \\
\hline Arellano-Bond m2 & & 1.0761 & 0.8695 & 0.7233 & 1.0761 \\
\hline Sargan Test & & 40.57 & 37.29 & 39.79 & 35.41 \\
\hline Number of Samples & & 204 & 204 & 204 & 204 \\
\hline Number of Group & & 51 & 51 & 51 & 51 \\
\hline
\end{tabular}

Source: Processed Data by Writer.

Table 8. Regression Results of Eq. 5 regarding Relationship of Firm performance and Executive Compensation to the Future Board Director Size using SYS-GMM

\begin{tabular}{|c|c|c|c|c|c|}
\hline \multirow{2}{*}{ Independent Variable } & \multirow{2}{*}{ Expected Sign } & \multicolumn{4}{|c|}{ Dependent Variable: BDS } \\
\hline & & (1) & (2) & (3) & (4) \\
\hline ROA & + & $\begin{array}{l}2.1736 \\
0.0070\end{array}$ & & & \\
\hline ROE & + & & $\begin{array}{l}0.8973 \\
0.0000\end{array}$ & & \\
\hline RET & - & & & $\begin{array}{c}-0.1143 \\
0.0000\end{array}$ & \\
\hline Q & - & & & & $\begin{array}{c}-0.0892 \\
0.0000\end{array}$ \\
\hline TECOMP & - & $\begin{array}{c}-0.4263 \\
0.0000\end{array}$ & $\begin{array}{c}-0.3485 \\
0.0000\end{array}$ & $\begin{array}{c}-0.2350 \\
0.0000\end{array}$ & $\begin{array}{c}-0.2816 \\
0.0000\end{array}$ \\
\hline BCS & \pm & $\begin{array}{l}0.0464 \\
0.2600\end{array}$ & $\begin{array}{c}-0.0287 \\
0.5740\end{array}$ & $\begin{array}{c}-0.0122 \\
0.7480\end{array}$ & $\begin{array}{c}-0.0421 \\
0.4890\end{array}$ \\
\hline IC & - & $\begin{array}{c}-0.0593 \\
0.8530\end{array}$ & $\begin{array}{c}-0.2068 \\
0.3730\end{array}$ & $\begin{array}{c}-0.0483 \\
0.8350\end{array}$ & $\begin{array}{c}-0.5852 \\
0.0700\end{array}$ \\
\hline ID & + & $\begin{array}{l}2.1438 \\
0.0020\end{array}$ & $\begin{array}{l}0.5686 \\
0.1740\end{array}$ & $\begin{array}{l}1.5259 \\
0.0000\end{array}$ & $\begin{array}{l}1.9460 \\
0.0000\end{array}$ \\
\hline FO & - & $\begin{array}{c}-0.4947 \\
0.0010\end{array}$ & $\begin{array}{c}-0.2917 \\
0.0270\end{array}$ & $\begin{array}{c}-0.8868 \\
0.0000\end{array}$ & $\begin{array}{c}-0.2385 \\
0.0650\end{array}$ \\
\hline ENC & + & $\begin{array}{c}-0.4938 \\
0.1350\end{array}$ & $\begin{array}{l}0.2548 \\
0.1660\end{array}$ & $\begin{array}{l}1.5868 \\
0.0000\end{array}$ & $\begin{array}{l}0.8866 \\
0.0020\end{array}$ \\
\hline $\mathrm{ECC}$ & - & $\begin{array}{l}0.0977 \\
0.7490\end{array}$ & $\begin{array}{c}-0.3158 \\
0.1010\end{array}$ & $\begin{array}{c}-1.6985 \\
0.0000\end{array}$ & $\begin{array}{c}-1.0834 \\
0.0000\end{array}$ \\
\hline $\operatorname{lnFS}$ & + & $\begin{array}{l}0.2462 \\
0.0000\end{array}$ & $\begin{array}{l}0.1951 \\
0.0030\end{array}$ & $\begin{array}{l}0.4315 \\
0.0000\end{array}$ & $\begin{array}{l}0.2524 \\
0.0000\end{array}$ \\
\hline FAGE & - & $\begin{array}{c}-0.0213 \\
0.0100\end{array}$ & $\begin{array}{c}-0.0068 \\
0.3010\end{array}$ & $\begin{array}{c}-0.0296 \\
0.0030\end{array}$ & $\begin{array}{l}0.0127 \\
0.3360\end{array}$ \\
\hline
\end{tabular}




\begin{tabular}{|c|c|c|c|c|c|}
\hline \multirow{2}{*}{ GO } & \multirow{2}{*}{+} & 0.0083 & 0.0039 & 0.0396 & 0.0319 \\
\hline & & 0.1140 & 0.4290 & 0.0000 & 0.0110 \\
\hline \multirow{2}{*}{ LEV } & \multirow{2}{*}{-} & 0.0211 & -0.0360 & -0.0218 & -0.0711 \\
\hline & & 0.1540 & 0.0020 & 0.0030 & 0.0000 \\
\hline \multirow{2}{*}{ IR } & \multirow[b]{2}{*}{ - } & -0.9518 & -0.2698 & 0.3365 & 0.3673 \\
\hline & & 0.0120 & 0.4540 & 0.3430 & 0.4130 \\
\hline \multirow{2}{*}{ BDS } & \multirow{2}{*}{+} & 0.8710 & 0.8680 & 0.7962 & 0.8803 \\
\hline & & 0.0000 & 0.0000 & 0.0000 & 0.0000 \\
\hline \multirow{2}{*}{ TECOMPt-1 } & \multirow{2}{*}{+} & 0.1746 & 0.2060 & 0.1328 & 0.1477 \\
\hline & & 0.0500 & 0.0330 & 0.1060 & 0.0360 \\
\hline \multirow{2}{*}{ ROAt-1 } & \multirow{2}{*}{+} & 3.3678 & & & \\
\hline & & 0.0000 & & & \\
\hline ROEt-1 & + & & $\begin{array}{l}0.0516 \\
0.7700\end{array}$ & & \\
\hline RETt-1 & & & \multirow{2}{*}{\multicolumn{2}{|c|}{$\begin{array}{l}0.0438 \\
0.0000\end{array}$}} & \\
\hline REIt-1 & + & & & & \\
\hline Qt-1 & + & & & & 0.0268 \\
\hline Arellano-Bond m1 & & 0.0013 & 0.0028 & 0.0038 & 0.0033 \\
\hline Arellano-Bond m2 & & 1.0761 & 0.8695 & 0.7233 & 1.0761 \\
\hline Sargan Test & & 30.12 & 31.75 & 35.91 & 35.26 \\
\hline Number of Samples & & 204 & 204 & 204 & 204 \\
\hline Number of Group & & 51 & 51 & 51 & 51 \\
\hline
\end{tabular}

Table 9. Regression Results of Eq. 5 regarding Relationship of Firm performance and Executive

\begin{tabular}{|c|c|c|c|c|c|}
\hline \multirow{2}{*}{ Independent Variable } & \multirow{2}{*}{ Expected Sign } & \multicolumn{4}{|c|}{ Dependent Variable :ID } \\
\hline & & (1) & (2) & (3) & (4) \\
\hline $\mathrm{ROA}$ & - & $\begin{array}{c}-0.1425 \\
0.0000\end{array}$ & & & \\
\hline ROE & - & & $\begin{array}{c}-0.0243 \\
0.0320\end{array}$ & & \\
\hline RET & + & & & $\begin{array}{l}0.0043 \\
0.0000\end{array}$ & \\
\hline Q & + & & & & $\begin{array}{l}0.0029 \\
0.0000\end{array}$ \\
\hline TECOMP & + & $\begin{array}{l}0.0047 \\
0.2210\end{array}$ & $\begin{array}{l}0.0213 \\
0.0000\end{array}$ & $\begin{array}{c}-0.0005 \\
0.9140\end{array}$ & $\begin{array}{l}0.0015 \\
0.7490\end{array}$ \\
\hline $\mathrm{BCS}$ & + & $\begin{array}{l}0.0016 \\
0.6590\end{array}$ & $\begin{array}{l}0.0070 \\
0.0040\end{array}$ & $\begin{array}{l}0.0035 \\
0.2740\end{array}$ & $\begin{array}{l}0.0042 \\
0.0920\end{array}$ \\
\hline IC & - & $\begin{array}{c}-0.0266 \\
0.2070\end{array}$ & $\begin{array}{c}-0.0548 \\
0.0060\end{array}$ & $\begin{array}{c}-0.0769 \\
0.0000\end{array}$ & $\begin{array}{c}-0.0442 \\
0.1410\end{array}$ \\
\hline BDS & + & $\begin{array}{l}0.0037 \\
0.1640\end{array}$ & $\begin{array}{c}-0.0033 \\
0.0820\end{array}$ & $\begin{array}{l}0.0027 \\
0.2820\end{array}$ & $\begin{array}{l}0.0049 \\
0.0910\end{array}$ \\
\hline FO & + & $\begin{array}{l}0.0196 \\
0.0630\end{array}$ & $\begin{array}{l}0.0023 \\
0.7500\end{array}$ & $\begin{array}{l}0.0285 \\
0.0000\end{array}$ & $\begin{array}{l}0.0113 \\
0.2830\end{array}$ \\
\hline ENC & - & 0.0254 & 0.0225 & -0.0650 & -0.0404 \\
\hline
\end{tabular}




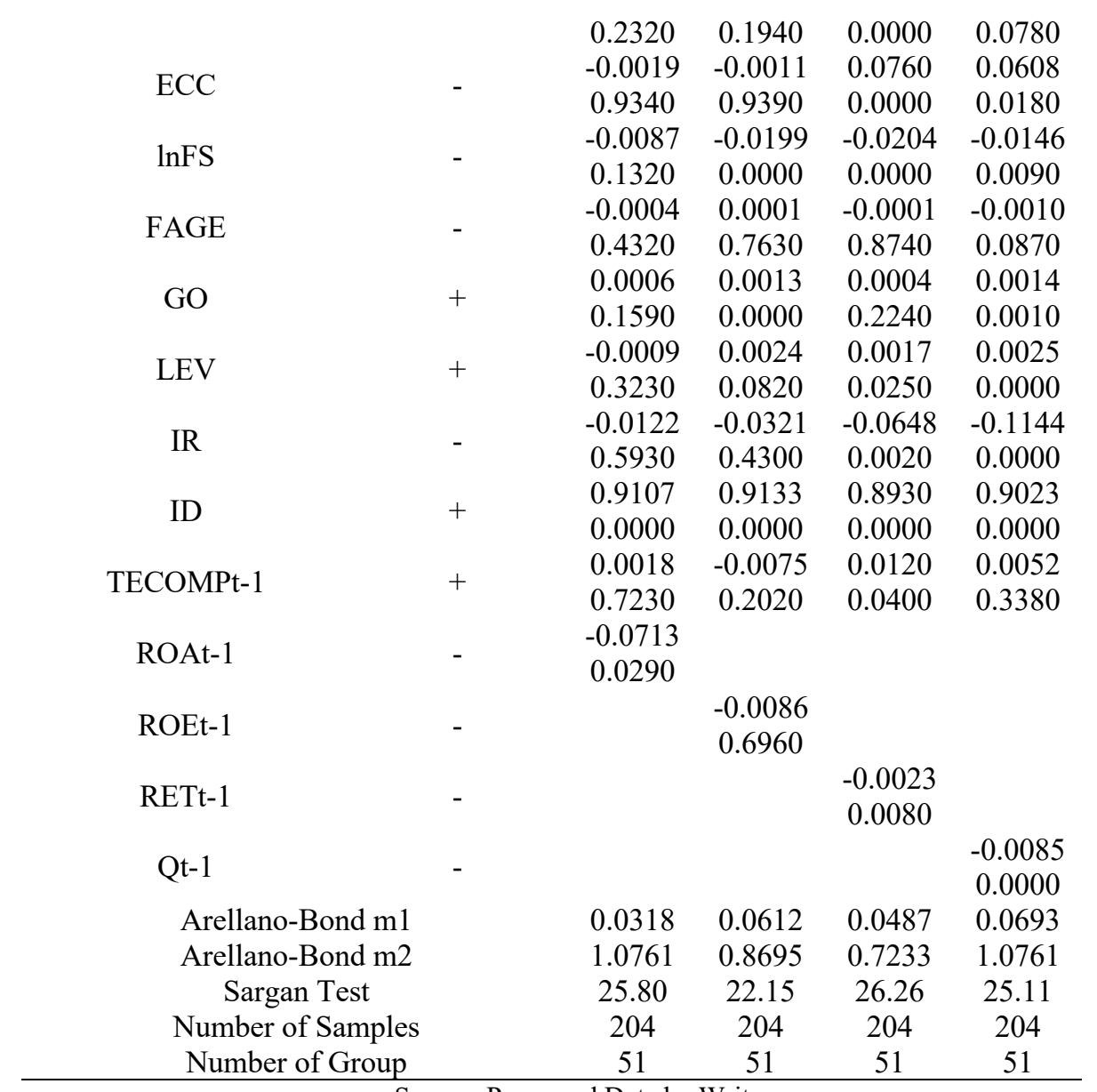

Source: Processed Data by Writer.

From the regression results of equations 3 to 6 , which company performance and executive compensation have different effects on corporate governance, especially when grouped into accounting and market-based performance. It appears that greater market-based performance (ROE and Q), the company tend to reduce the number of boards of directors and the supervisory function of the commissioners, both the number of commissioners and the proportion of independent commissioners, but increase the proportion of independent directors. Meanwhile, the greater executive compensation, the company will increase the supervisory function of the board of commissioners and increase the number of boards of directors and reduce the portion of the independent board of directors.

\section{Conclusion}

From this study, it can be concluded that executive compensation, corporate governance, and company performance are related to each other and also have a reciprocal relationship with each other. So, by utilizing these linkages, management can take strategic steps in determining 
methods of managing corporate governance and executive compensation to improve company performance, such as when the company's performance improves and has executive compensation at its optimum, the company can use less monitoring. Conversely, when performance deteriorates, the company should improve monitoring and management of the company, but there is no need to motivate executives by providing optimum compensation because executive compensation does not have a significant impact on performance.

In addition, this linkage can also be used in selecting companies to invest. Investors and creditors can consider companies with good corporate governance as the main factor in investing, because with good corporate governance, the company's performance will improve, especially if it measures market-based performance which reflects the company's current condition from the public.

\section{References}

[1] S. The Jakarta Consulting Group on Family Business, Jakarta: The Jakarta Consulting Group, 2007.

[2] M. Jensen dan W. Meckling, "Theory of the firm: Managerial behavior, agency costs, and ownership structure," Journal of Financial Economics, Vol. \%1 dari \%23, No. 4, pp. pp. 305-360, 1976.

[3] E. F. Fama dan M. C. Jensen, "Separation of Ownership and Control," Journal of Law and Economic, vol. 26, 1983.

[4] J. S. C. Ang, A. Rebel dan L. Wuh., "Agency Cost and Ownership Structure," The Journal of Finance, vol. LV, pp. 81-106, 2000.

[5] S. M. Puffer dan J. B. Weintrop, "Corporate performance and CEO turnover: The role of performance expectations," Administrative Science Quarterly, vol. 36(1), pp. 1-19, 1991.

[6] C. Florackis, "Agency costs and corporate governance mechanisms: Evidence for UK firms," International Journal of Managerial Finance, vol. 4(1), p. 37-59, 2008.

[7] R. C. Anderson dan J. M. Bizjak, "An empirical examination of the role of the CEO and the compensation committee in structuring executive compensation," Journal of Banking \& Finance, vol. 27(7), p. 1323-1348, 2003.

[8] J. Sun, S. F. Cahan dan D. Emanuel, "Compensation committee governance quality, chief executive officer stock option grants, and future firm performance.," Journal of Banking \& Finance, vol. 33(8), pp. 1507-1519, 2009.

[9] J. Nelson, "Corporate governance practices, CEO characteristics and firm performance," Journal of Corporate Finance, Vol. \%1 dari \%211 (1-2), pp. 197-228, 2005.

[10] L. F. Klapper dan I. Love, "Corporate governance, investor protection, and performance in emerging markets," Journal of Corporate Finance, vol. 10(5), pp. 2423-2432, 2004.

[11] K. Ramaswamy, M. F. Li dan R. Veliyath, "Variations in ownership behavior and propensity to diversify: A study of the Indian corporate context," Strategic Management Journal, vol. 23(4), pp. 345-358, 2016.

[12] M. A. Valenti, R. Luce dan C. Mayfield, "The effects of firm performance on corporate governance.," Management Research Review, vol. 34(3), pp. 266-283, 2011.

[13] . P. Limpaphayom dan J. T. Connelly, Review of Corporate Governance in Asia: Corporate governance in Thailand, Thai Institute of Directors Association, 2004, pp. 30-33.

[14] C. G. L. S. O. K. A. \&. T. D. A. Ntim, "Executive compensation, corporate governance and corporate performance: A simultaneous equation approach.," Managerial and Decision Economics, vol. 36(2), p. 67-96, 2015.

[15] B. H. Baltagi, Econometric Analysis of Panel Data, New York: John Wiley \& Sons, 2005.

[16] . M. A. Carpenter dan W. M. G. Sanders, "Top management team compensation: The missing link between CEO compensation and firm performance?" Strategic Management Journal, vol. 40(1), p. 367-375, 2002.

[17] M. A. Carpenter dan W. M. G. Sanders, "The effects of top management team compensation and 
firm internationalization on MNC performance.," Journal of Management, vol. 30(4), p. 509-528, 2004.

[18] M. J. Conyon, "Executive compensation and board governance in US firms," Executive compensation and board governance in US firms, vol. 124(574), pp. F60-F89, 2014.

[19] J. E. Core, R. W. Holthausen dan D. F. Larcker, "Corporate Governance, Chief Executive Officer Compensation, and Firm Performance,” Journal of Financial Economics, pp. 371-406, 1999.

[20] T. Swatdikun, "Executive Pay-Performance Sensitivity and Its Consequences: Empirical Evidence on The Role of Ownership in Thailand.," in Doctor of Philosophy Thesis, University of Southampton, 2013.

[21] M. Raithatha dan S. Komera, "Executive Compensation and Firm Performance: Evidence from Indian Firms," IIMB Management Review, pp. 160-169, 2016.

[22] R. M. Cyert, K. Sok-Hyon dan P. Kumar, "Corporate Governance, Takeovers, and TopManagement Compensation: Theory and Evidence," Management Science, pp. 453-469, 2002.

[23] M. J. Conyon dan L. He, "CEO compensation and corporate governance in China," Corporate Governance: An International Review, pp. 575-592, 2012.

[24] M. J. Conyon dan S. I. Peck, "Board control, compensation committees, and top management compensation," Academy of Management Journal, pp. 146-157, 1998.

[25] Y. Luo dan D. Jackson, "Executive Compensation, Ownership structure and Firm performance in Chinese Financial Corporations," Global Business and Finance Review, pp. 56-74, 2012.

[26] R. Blundell dan S. Bond, "Initial Conditions and Moment Restrictions in Dynamic Panel Data Models," Journal of Econometrics, pp. 115-143, 1998. 